\title{
Artists' Books in the University Libraries
}

\author{
TIMOTHY SHIPE and HARLAN SIFFORD
}

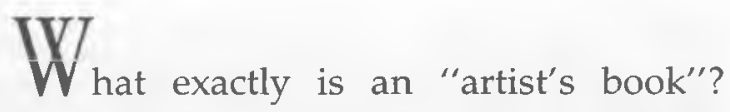

There seem to be almost as many competing definitions for the term as there are for the word "art." Clive Phillpot, head librarian of New York's Museum of Modern Art, has what may be the most straightforward definition: a "book of which an artist is the author."1 Art critic Lucy Lippard provides a somewhat narrower definition that better reflects the scope of the present article: "Neither an art book (collected reproductions of separate art works) nor a book on art (critical exegeses and/or artists' writings), the artist's book is a work of art on its own, conceived specifically for the book form and often published by the artist him/herself." 2

It is useful, if not always accurate, to distinguish the "artist's book" from the "illustrated book." From the earliest history of the codex or manuscript book, artists have worked with the medium. Early religious texts were interpreted by artists' illuminations to add visual enrichment to the text for those who could read and to explain the contents to those less fortunate. In the twentieth century, artists have often chosen to illustrate text or to produce sets of drawings or prints and design the

${ }^{1}$ Clive Phillpot, "An ABC of Artists' Book Collections: Introduction," Art Documentation, 1.6 (Dec. 1982), 169.

${ }^{2}$ Lucy Lippard, "The Artist's Book Goes Public," in Artists' Books: A Critical Anthology and Sourcebook, ed. by Joan Lyons (Rochester, N.Y.: Visual Studies Workshop, 1985), 45-48. 
formats for published literary works. Matisse, Picasso, and Chagall made important contributions in this area of publishing.

But for an artist's book in the stricter sense, the artist is generally the creator of both image and text. This is not an entirely new phenomenon. We can find precedents at least as early as William Blake's works, many of which combined word

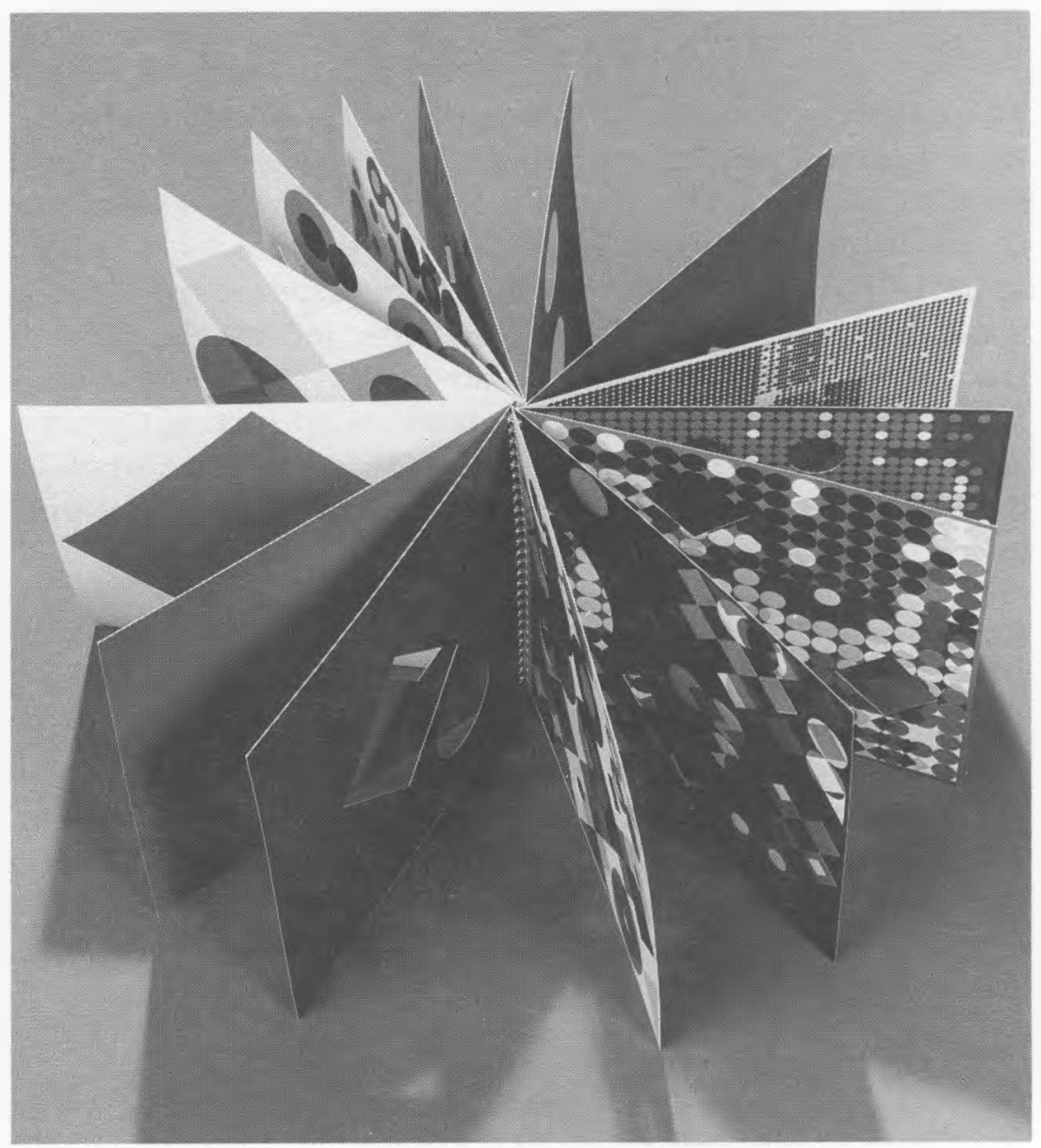

Dieter Rot's Kinderbuch (1976). From the University Libraries. 
and image as an inseparable unity. One might even cite earlier forms of visual literature such as Renaissance emblem books and pattern poems. More direct precursors are two very different publications by Marcel Duchamp from the 1930s. The Green Box of 1934 was an enormous, lavish, limited edition box containing carefully produced facsimiles of notes and diagrams for Duchamp's "Large Glass", one of the seminal art works of the century. Rrose Sélary (1939), on the other hand, was a small, unillustrated booklet consisting entirely of enigmatic, often erotic puns. These works anticipate several different trends in the contemporary artist's book. Predecessors in the fifties and early sixties include the concrete poets (some of whom experimented not only with the placement of words and symbols on the page, but also with the physical form of the book), experimental art magazines like Aspen and SMT, and the publishing ventures of the Fluxus artists.

However, the artist's book as we know it has its origins in the 1960s; it developed largely as a means of creating an art form that would be independent of the gallery system. A book could be produced inexpensively, and could potentially be distributed to a much wider audience than other art forms. Typically, artists' books in the formative years of the medium were printed in relatively large runs and sold for under ten dollars. They were conceived as a democratic, non-elitist art form; some artists dreamed of seeing their book works sold in supermarkets alongside the tabloids. The best-known examples of this early phase are the works of Ed Ruscha, small booklets of photographs with plain covers displaying titles which precisely describe their contents: Twentysix Gasoline Stations, Thirtyfour Parking Lots, in Los Angeles, and so on. In the intervening quarter-century the medium has blossomed in countless directions. There is little agreement on its precise boundaries. However, one can certainly generalize about some trends.

An artist's book may consist entirely of pictorial material (Leon Golub's Facings, Ellen Lanyon's Transformations I), entirely of text (Anna Crowell's Child Abuse), or of a mixture of text and image (Gail Rubini's Forever Yours, Rebecca Michaels' 


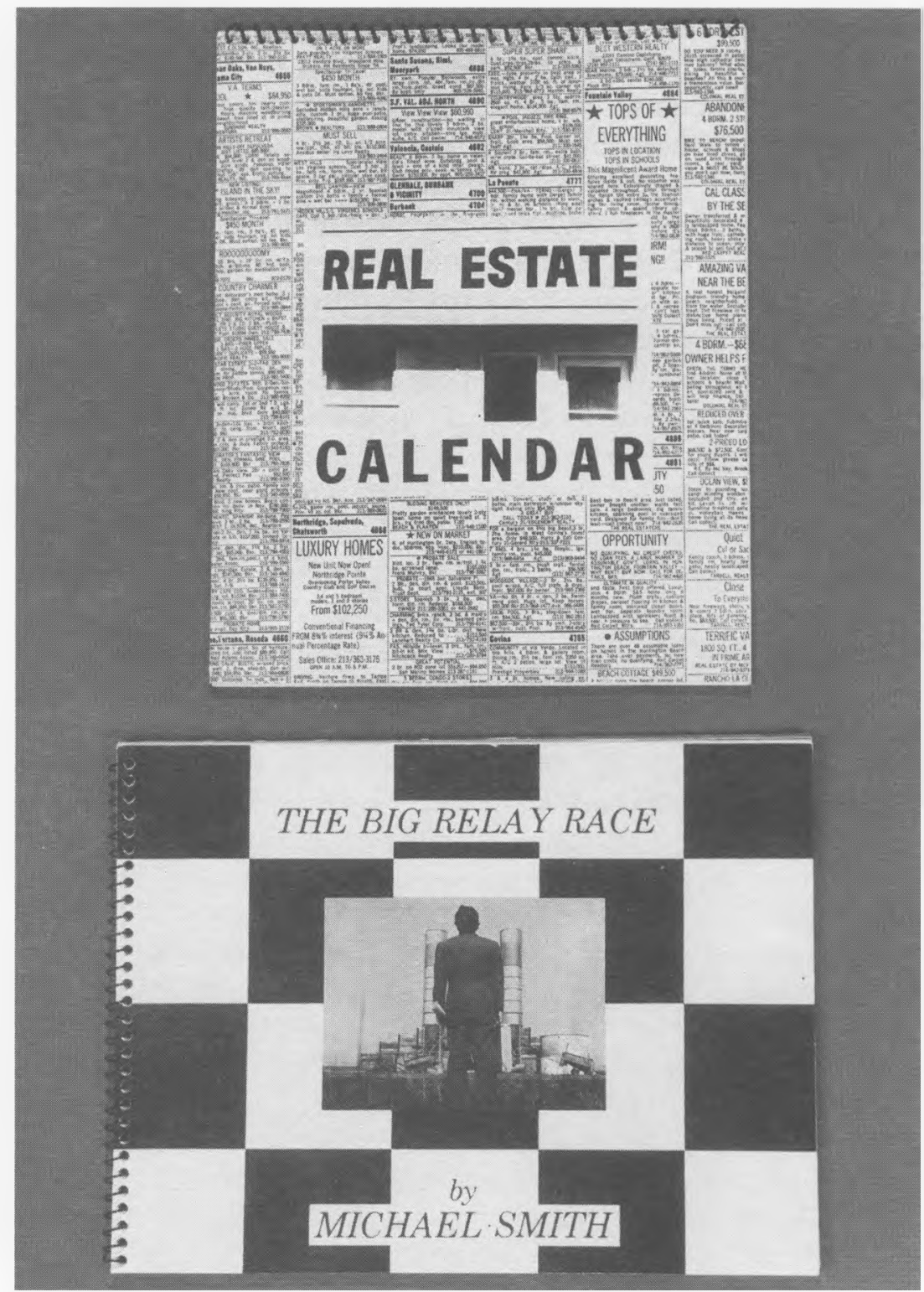

Nancy Webber's Real Estate Calendar (1977); Michael Smith's The Big Relay Race (1981). From the University Libraries. 
The Courtship Patterns of Chairs). Generally, the conventional reading sequence of the European book, from front to back (left to right), is assumed; often a narrative development will rely on this sequence (Michael Smith's The Big Relay Race). Sometimes, though, the "reader" is invited to create his or her own sequence by entering the book at any point, viewing the pages in any order (Dieter Rot's Kinderbuch). Still other works are so constructed as to completely frustrate the desire to read in a "normal" sequence (Brian McBean's Untitled). Some artists' books masquerade as other kinds of publications, playing with their conventions: there are artists' books in the form of calendars, stockholders' reports, tabloid newspapers, comic books, and games (Nancy Webber's Real Estate Calendar, Judy Levy's $59_{\mathbb{L}}$ Life). Some works incorporate previously published books, modifying them to create new works (Tom Phillips' A Humument). Some call into question the very physical structure of the book, forcing us to wonder whether we can even call them "books" (Conrad Gleber's Meat Book, Carol Alonge's White Sands, Susan Wick's Paper Towel Book). Many critics prefer to place these works in the separate category of "book objects."

As a general rule, the artist is responsible for the textual as well as the visual "content." However, collage techniques are frequently used, and an artist's book may consist entirely of a juxtaposition of borrowed images or quoted texts (Steven Cortright's East-West). A common type of artist's book documents a conceptual or performance piece; such a book becomes the only permanent trace of an ephemeral art work (Vida Freeman's Northridge Project, Bob Roesler's KxYz). One major trend has been toward political-social criticism, particularly from a feminist viewpoint; this certainly has much to do with the medium's origins as an alternative to the power structures of existing artistic institutions (Hans Breder and Barbara Welch's Portrait of Rosa, Kevin Hamilton's The Day of the Rope). The inexpensive production methods of most artist's books is also in keeping with this revolt against the economic power structures of mainstream art. However, there has also been a recent trend toward producing expensive, limited edition art- 
ists' books (Walter Hamady's Neopostmodrinism). This trend has caused consternation among certain of the artists' book makers who wish this medium to be easily available to all who might be interested. Lawrence Weiner, who has been producing artists' books since 1969, has warned of "an American artists' book 'industry' perilously threatened by its own success." 3

A significant number of artists' books in the University Libraries' collections come from the influential exhibition "Artwords and Bookworks," first shown at the Los Angeles Institute of Contemporary Art in 1978. After the exhibition had traveled around the country for several years, the entire collection was donated to The University of Iowa; it now forms part of the University Libraries' collection in association with Alternative Traditions in the Contemporary Arts, a program of the School of Art and Art History. The Libraries also house a large collection of works from University of Iowa faculty member Jim Snitzer's Chicago Book project.

In the recent exhibition "Book as Image," which we curated with the assistance of Pamela Spitzmueller, a selection of artists' books from the holdings of Special Collections and the Art Library was displayed. It is interesting to ask how these ephemeral titles came to be part of a library's collections, rather than ending up in a museum. One explanation is that they are called "books," and libraries are supposed to collect books. A second explanation is that, in many cases, these works are not of sufficient monetary value to be prestigious additions to a museum's collection, even when they are one-of-a-kind artifacts. This was certainly the case when artists' books first started being produced. Now that the value of those early works has been recognized, and their monetary value has increased, museums seem to have considerably more interest in acquiring them. But there are definite advantages to housing artists' books in libraries, where they can be used, rather than in museums, where they can only be viewed. The chief

${ }^{3}$ Lawrence Weiner, quoted in: Nancy Princenthal, "Artist's Book Beat," Print Collector's Newsletter, 20.6 (Jan.-Feb. 1990), 225-27. 


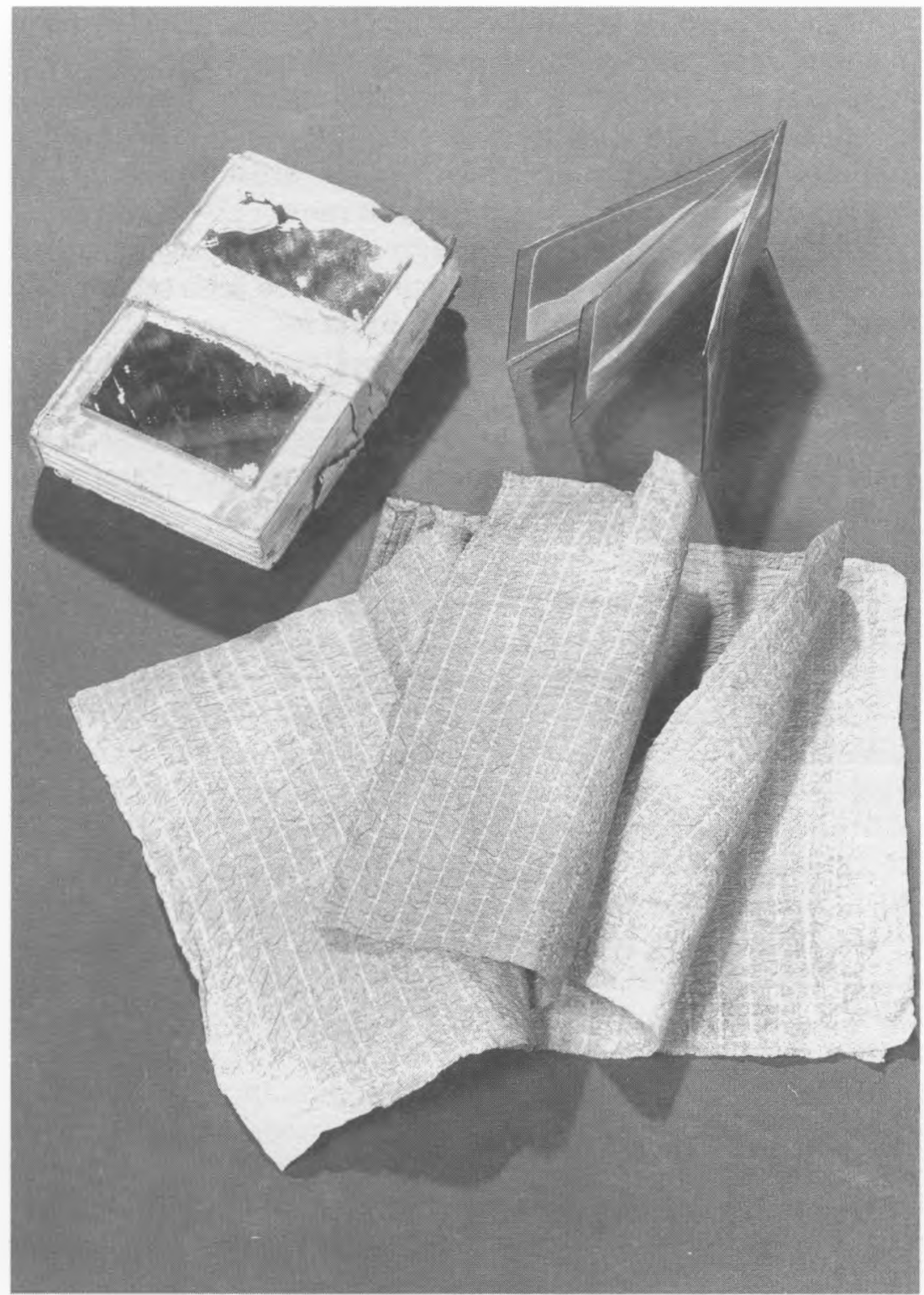

Brian McBean's Untitled (1977); Carol Alonge's White Sands (1977); Susan Wick's Paper Towel Book (1977). From the University Libraries, in association with Alternative Traditions in the Contemporary Arts. 
problem in keeping artists' books in a museum is that displaying the works statically, in glass cases, undercuts the very intention of the medium. The artist's book is meant to be handled, read, seen in its entirety either in sequence or at random. To display a few pages of an artist's book is like looking at a few stills from a movie-it cannot give a real sense of the work as a whole. The museum setting defeats the artists' dream of a democratic art form that could be seen by anyone, freed from the walls of museums of fine art.

Now that artists' books have been widely written about and anthologies and bibliographies have been compiled, it is fortunate that the University Libraries began acquiring these items early on as part of its longstanding interest in and commitment to the medium of the book in all its diversity. 